\title{
The Cape York view
}

\author{
Richard Ah Mat
}

\section{We have to get real about the Holy Grail}

Who reading this knows what is a Holy Grail or what is the Holy Grail? We've all probably used the phrase 'we're searching for the Holy Grail', 'I found the Holy Grail', but how many of us have ever understood what in the hell it is? Many of us have probably used the phrase to express the search for or achievement of goals a lot less lofty, a lot less chivalrous, a lot less spiritual - than was intended by the saintly people of medieval times.

Until two days ago I too had no clue what the hell the Holy Grail was. And I've seen as many movies about knights in armour galloping around on horses as anyone. I've even seen the movie with the knights who gallop around on their own two legs, clapping coconuts together.

To this day I've never known what the Holy Grail was. I just had some vague thought that it was some kind of cloak or robe ... or was it King Arthur's sword ... or what the hell was it? Anyway this is the definition that the dictionary on Microsoft Word gives of the Holy Grail:

... according to medieval legend, the cup said to be used by Jesus

Christ at the Last Supper, and by Joseph of Arimathea to collect his

blood and sweat at the Crucifixion.

The notion of a treaty between the Indigenous people of Australia and the Commonwealth Government on behalf of the non-Indigenous people of Australia - has become something of a Holy Grail to progressive politics in our country.

The Treaty has become a Holy Grail for a number of reasons.

One reason is that the Treaty is seen as the ultimate political destination for the Aboriginal rights movement. It is political heaven. It is that point over the horizon where reconciliation prevails and everything is sweetness and light. It is the place where the meek inherit the earth and all social and economic ills are a thing of the past. Wounds will be healed, the blind will see, the lame shall walk again. If not Heaven on Earth, then it may be the kind of utopia that the socialists had in mind when they dreamed of a better future for the workers of the world.

I am of course slightly exaggerating the hopes that people have for a treaty - but probably not as much as I think. The Treaty is seen as some kind of Nirvana.

Another reason is that the Treaty represents the legal and political instrument that will put paid to all ambiguity and argument. It will be a final settlement of all political and legal disputation 
about the place of Aboriginal people in the Australian nation. It will be the mother of all comprehensive settlements, and it will contain every solution to every conceivable problem - including those things that we cannot now conceive of as issues to resolve.

Like the Holy Grail, we are all agreed on its fundamental importance and that it is the crusade that we must all embark upon - and yet we are unclear what we mean by it. We are very vague about what the destination is that we are seeking. To what new land over the horizon are we seeking to travel? And how will we know when we have arrived? What will the Holy Grail look like if we don't have a detailed picture of it? Do we have anything more detailed than some generally misty, cloudy place behind which lies a place called Heaven?

And how come we have been talking about a treaty for nearly three decades now and yet our general understanding of it is not a great deal advanced beyond the concept of some kind of profound agreement between black and white? We are still unclear on basic questions like:

- who will be the parties to the Treaty?

- who will represent the Aboriginal parties?

- what authority will the Aboriginal parties have to negotiate the Treaty?

- what authority will they have to sign the Treaty?

- is there a treaty or treaties?

Or has the quest for the Holy Grail become more important than actually finding it? Will we be psychologically capable of seizing the Grail when we come upon it? Will we be prepared to pull the sword from the stone? Or is our hesitation about reaching such a moment of historical decisiveness - where we have to make a settlement with those who have colonised our people and our country - the thing that makes it more comfortable for us to float around in a fog of vagueness, rhetoric and mournful hope?

The message from the leaders from my region is this: we have to get real about the Holy Grail. We can't continue to stumble around - in full metal armour - on poor, bony and starving horses - charging at windmills on the horizon. We need first:

- to know what we are looking for;

- to work out a plan to get there; and

- to ride forward deliberately and carefully, and in accordance with the plan.

Those of us with our heads in the clouds must think about descending to planet Earth, or at least somewhere approximately within orbit of it. ATSIC must stop authorising any travel request forms for those who wish to continue their travels to Outer Space. Those of us who are plunging swords into the backs of our troops and who are using our leaders for archery target practice - must attend re-training classes so that we can properly recognise who the real enemies are. Those of us who are devouring our own horses must reconsider the wisdom of doing this and realise that we will have need for them in the long march ahead of us.

The point is: we have to get real. If we're gonna talk about a treaty, let's talk in the here and now. Let's be ambitious, but let us also be realistic. Let's be hopeful, but let's not be naive. Above all, let us realise that we are not seeking to recreate heaven on earth. We are instead 
seeking a political and moral reconciliation between the old and new Australians in relation to matters of great significance and importance to human beings who live in a real world, whose futures must necessarily be founded upon coexistence.

\section{The lessons from ' 67}

The first reality check that we have to face up to is this: what lessons do we take from the 1967 Referendum which finally recogniseded Aboriginal people as Australians citizens?

Before I talk about what we from Cape York think are the lessons from '67, let me first clarify that I am talking about the concept of a treaty which is founded upon amendment of the Australian Constitution. I am not talking about treaty in the sense of an agreement between two international nations, and I am not talking about an agreement that is set out in legislation enacted by the Commonwealth Parliament. I am talking about what I think we should be talking about - that is, a treaty that is backed by amendment to the Australian Constitution.

Now the lessons that we should take from 1967 are pretty obvious. They are as follows:

1 The '67 Referendum was passed by 90 something per cent of the Australian electorate. We are constantly told that the Australian Constitution is one of the hardest constitutions in the world to change, because you need 'a majority of voters in a majority of the States'. So you need $80-90 \%$ of the country to support the change.

2 To get $80-90 \%$ of the country to support a Referendum, you need bipartisan political support. And you need support from the States and Territories as well, so that they're not running a 'NO' case against you.

3 In order to get bipartisan support, you will need a conservative government to propose the amendment and you need Labor to offer bipartisan support. It is unlikely that you will get bipartisan support the other way around. In 1967 the conservative government of Harold Holt proposed the amendment and it was supported by the Whitlam Labor Opposition.

4 To get $80-90 \%$ of the country you need to convince rural, conservative and regional Australia of the need for change. In other words you need to convince those people who usually vote for the National Party.

5 It took 10 years of outstanding and dignified advocacy by Indigenous leaders like Faith Bandler and the late Pastor Doug Nichols and many others, to build the groundswell of support across the political spectrum. The Indigenous leadership of this period was smart, dignified, very capable and very united. This is in sharp contrast to our leadership today.

Those who think that the Treaty is somehow a 'radical' cause or a 'radical' option, need to think again. If you want a treaty to turn into reality you need to have a strategy of convincing conservative and regional Australia in favour of your cause. Do you really think that conservative and regional Australia are going to simply put their hands up and say 'YES' to something that is sold to them as a radical cause? 
We have to get real. If we talk treaty, we need to talk about how we're going to get $80-90 \%$ of the country to back us in a referendum. Otherwise we are just kidding ourselves.

One last lesson that we should take from '67. The question of recognising Aboriginal people as citizens of Australia was a pretty easy question in the whole scheme of things. It would have been ridiculous for Australia to have gone on much further in its history without addressing this racist exclusion of its Indigenous peoples from the Constitution. White Australia was not being asked to give anything substantial to black fellas in 1967.

When we talk about a treaty that is aimed at settling questions to do with the rights of our people and dealing with contentious questions of land rights, economic development and governance - then you really are asking the hard questions. The constitutional change needed to underpin a treaty is a much harder and a much more complicated question than the question of whether Aboriginal people should be counted as citizens of their own country.

\section{We must show that self-determination can work in practice - and we must get ourselves organised at the regional level}

The question of self-determination and governance will be central questions for a treaty. It is sure to be one of the most contentious issues.

Our view from Cape York is that we must show that self-determination can work in practice - on the ground, in our regions, in our communities, in our traditional owner groups. The problem with our talk about self-determination, is that in practice we are severely disorganised and disunited. So whilst self-determination is easy to talk about in theory, we are not translating it into reality - and doing the hard yards to make Indigenous governance work amongst our people.

The levels of disputation, division, jealousy, infighting, power-plays, backstabbing, mistrust are very, very high amongst our people. Our organisations don't work together. Leaders won't cooperate with one another, whether at the community or the regional or the national levels. There is a breakdown of Aboriginal Law and authority, and as a result our families and communities are falling apart with no law and order. Our social problems are in no small part due to the breakdown of governance within our own communities.

If we won all of the necessary legal and political victories tomorrow to give us the fullest right to self-determination within this country - what would it mean in reality? I don't think it would mean much. It would not mean much because self-determination is about practice, it is about actions, it is about what we do from day to day to make changes, it is about governance. It is about taking responsibility for our problems and for our opportunities: because nobody else will take responsibility for our families, our children, our people. We have to do it ourselves.

Our view from Cape York is that we must get organised around the regions. There are, and there always will be, three main levels of Aboriginal community - national, regional and local. We believe that the regional level of governance needs to be developed. We need Aboriginal organisations to be united and working together at the regional level. It is at this level that our people can have the necessary scale and political organisation and capacity - to deal with governments and the outside world. It is also the level that our people need to develop economically and to carve out a place in the wider regional economies in which Aboriginal people are located. 
Regional organisation is still under-developed. We have been working in Cape York for the past 10 years, putting together the foundations of regional governance and self-determination. We now have:

- The Peninsula ATSIC Regional Council

- Tharpuntoo Aboriginal Legal Service

- Cape York Land Council

- Apunipima Cape York Health Council, and

- Balkanu Cape York Development Corporation

We also now have Cape York Partnerships as an interface for partnerships with government and external non-government sectors. We have endeavoured to develop unity, common purpose and vision for the future of Cape York. To develop plans and strategies, and to work together towards their achievement. It has been - and it is still - hard work. But we believe that getting organised regionally is a necessary part of development of our people at the local level. If we don't get organised regionally, we can't represent the local level in the ways that are needed in order to deal with governments and the outside world. In developing ourselves at the regional level in Cape York, we are also conscious that if a national agreement in the form of a treaty is to be reached agreements at the regional level will be necessary.

In fact any future treaty is likely to set a framework and general principles whilst the agreements of substance are negotiated and settled at the regional level. The concept of regional agreements - which has disappeared from discussion in this country in recent years - are probably going to be the only way treaties can be implemented in practice.

\section{How do we get $80-90 \%$ of the country to support a treaty?}

My Cape York colleague, Noel Pearson, explains the difference between what he calls 51\% and $80-90 \%$ strategies.

$51 \%$ strategies are strategies that we use when we need:

the Government of the day to make some policy or administrative

decision that we want, or

we need the Government of the day to get legislation passed by the

Commonwealth Parliament

It means we only need to convince one side of politics (usually the Left side of politics) to champion a particular issue - and as long as they carry $51 \%$ of the country behind them, we can get executive or legislative victories.

When we pursue $51 \%$ strategies, our main challenge is to convince those who are in power to do the right thing. It doesn't matter if the other Right side of politics goes against us - as long as the Left have $51 \%$, we can get a result.

But of course convincing the Left, when it is in power, is not an easy thing. They are always afraid that if they agree to what we want, they will go from $51 \%$ to $49 \%$ at the next election.

But, $51 \%$ strategies won't work if we are talking about a treaty and constitutional change. As we have already discussed, if we want to change the Australian Constitution we need 'a majority of voters in a majority of the states'. That is, we need an $80-90 \%$ strategy. 
We in Cape York are of the view that $80-90 \%$ strategies are fundamentally different from $51 \%$ strategies. Let me make four points about the differences:

1 Firstly, if you want $80-90 \%$ of the electorate to support our cause, we have to work counter clockwise - from the Right to the Left. We have to convince the people on the furthest Right. In other words, we have to convince the National Party's regional and conservative constituency. If we can convince these people to treat with us, then everybody else to the Left of them should fall into position.

2 Secondly, the people on the furthest Right must be made the primary owners and the primary advocates of a treaty deal with our people. It is only by them making the deal, and playing the leading role in such a reconciliation, that they will then champion the treaty. If the treaty is owned as an issue and championed by the Left, we will get nowhere with the Right.

3 Thirdly, the more we push the treaty through $51 \%$ strategies - that is, as a movement starting from the Left and moving rightwards - the greater the likelihood that the Right will oppose it, and we will never build the $80-90 \%$ constituency we need to get constitutional change. The Bridge Walkers, the Reconciliation Movement and so on - these are $51 \%$ strategies.

4 Fourthly, we get nowhere if we spend all of our energy and time preaching to the converted (or to the people who are easy to convert). Never mind this mob - they're the easy ones. Let's now think hard about how we're gonna swing the hard nuts.

So the big political questions facing those who advocate a treaty are these: is it at all imaginable that we could find common ground with conservative and regional Australia such that they would support a treaty? In what conditions could this scenario come about? What would we need to do to locate this common ground?

These are not easy questions to answer. But we must turn our minds to them. Because the reality is this: if we can't find common ground with the National Party and its conservative and regional constituency - then we can't get a treaty in the form of constitutional change.

The treaty must start in the bush and then move to the cities. If we develop the treaty in the cities and try to take it out into the bush - the bush will kill it.

\section{What is involved in moving towards a treaty?}

Let me very briefly summarise the ingredients necessary to bring a treaty into existence.

- 5\% involves legal and political theory. This is what we are doing at this Conference. This is what we have been doing at all of the other conferences and seminars on the subject of the treaty. We have not made much progress with the theory, because our thinking about the details is still largely stunted.

The point that we from Cape York want to make about the theory is this: theory is important, but let's understand that it is only a small part of what is needed to get a treaty. 
- 5\% involves developing and deciding on the constitutional mechanism. This is very, very important. But it is also the easy part and is only $5 \%$ of our challenge.

- $90 \%$ of the challenge involves political strategy and prosecution of the strategy. This is the hard work. This is about lining all of the planets up. This is about herding a million feral cats dispersed throughout bushlands all over the continent. This about lining up all of the thousands of ducks in the Kakadu wetlands into one orderly line. This is the truly hard business.

\section{Conclusion: leadership and unity}

It is our belief from Cape York Peninsula that the achievement of a treaty between the Indigenous peoples of Australia and the Commonwealth on behalf of the non-Indigenous peoples of Australia - is a conceivable reality. It is within the realms of possibility.

But if a treaty is to be reached, then there will need to be leadership and unity amongst the Indigenous peoples of Australia. If we are united and we recognise and support our leadership - then I have no doubt we could get there. We have the people. We have the opportunities. In fact, it is probably true that there has never been a better time for us to move to a treaty, than now. Will we have the unity and will we be clever enough to recognise the opportunity and make the plans and strategies so that we can reach the Holy Grail? 